\title{
Negatividade, cisão, reconciliação: indicações sobre a concepção do negativo em Hegel, e a radicalização da finitude em Sartre e Freud
}

\author{
Negativity, scission, reconciliation: indications about the \\ negativity conception in Hegel and the radicalization of failure \\ in Sartre and Freud
}

\author{
Fábio Moreira Vargas \\ Graduação em andamento em Filosofia (2013), Universidade de São Paulo. USP, São Paulo, SP - Brasil.
}

\begin{abstract}
Resumo: O presente artigo procura elucidar aspectos da noção de negatividade em três autores. Inicia-se pela consideração à filosofia hegeliana, demonstrando que a atenção dada ao negativo por este último, ainda que central, não culmina numa radicalização da noção de negatividade, tendo, pois, seu escopo central na pregnância da mesma estrutura hegemônica da filosofia ocidental, a ideia de identidade e totalidade. Em seguida, investigaremos a radicalização da noção em Sartre, através da absolutização da experiência negativa sem possiblidade de síntese, ou reconciliação (como no pensamento hegeliano). Por fim, situaremos Freud como um autor que também radicaliza a noção do negativo. Através da breve exposição sobre a interpretação da religião, o psicanalista pode revelar uma concepção de homem marcado pela insuficiência, e o desamparo, isto é, uma concepção negativa. Palavras-chave: Negatividade; cisão e desamparo; totalidade e síntese; Hegel; Sartre; Freud.

Abstract: This article aims to show aspects of the notion of negativity in three authors. It begins with Hegel's philosophy and elucidates that the attention given to the negativity by this author is central, but it does not finish in the radicalization of the negativity notion. Thus, in Hegel, the negativity remains in the same hegemonic structure of the western philosophy, namely the ideas of identity and totality. Next, we will investigate the radicalization of the notion of negativity in Sartre. Through the absolutization of negative experience, without possibility of synthesis or reconciliation (as in Hegelian thought). In the end, we will locate Freud as an author who also radicalizes the negativity notion. Through a brief exposition on the interpretation of religion, the viennese psychoanalyst can show his conception of the human being. And this man is marked by failure and helplessness; this is, a negative conception.
\end{abstract}

Keywords: Negativity; division and helplessness; totality and synthesis, Hegel; Sartre, Freud. 


\section{Da cisão à identidade: o hegelianismo. ${ }^{1}$}

É preciso concordar com Bornheim em que "a metafísica ocidental concede primazia ao princípio de identidade, e reduz, de um modo geral... a contradição à identidade" (BORNHEIM, 1971 p.148), e situar os maiores nomes do pensamento ocidental comprometidos, cada qual à sua maneira, com essa querela persistente. O heraclitismo impôs, por muito tempo, dúvidas incômodas à real possibilidade de superar esta cisão, no horizonte mesmo de cada tentativa sempre havia a força da desestruturação encarnada pela mudança, pela impossibilidade da mínima predicação. Heráclito, "o obscuro", e a contradição posta no real era um inimigo de todos. Da ideia platônica em contraponto ao mundo das sombras, "compromisso do ser com o não-ser", à apresentação do Cogito cartesiano na supressão da dúvida pela hegemonia da res cogitans - princípio máximo de identidade de si para consigo mesmo - a tradição sempre se incomodou com a separação, a cisão, o não-ser. Mesmo Kant, que devidamente anunciou a contradição como algo inerente à própria razão, não levou tão longe a concepção do negativo. A auto atividade como síntese do Eu, idêntico a si e garantia máxima do próprio conhecimento, é um exemplo de como Kant permanece fiel à identidade. Pode-se mesmo pensar que a tradição metafísica tem horror de tudo aquilo que não seja idêntico, pleno, Ideia.

Há autores que consideram ser o mérito incontornável de Hegel inverter esta velha situação. A contradição seria agora o lugar privilegiado, chegando mesmo a considerarem que a identidade figuraria em segundo plano, e assim, Hegel distanciar-se-ia radicalmente de toda história da filosofia. Essa caracterização encontraremos em Fougeyroalls: "aquilo no que e por que Hegel difere... de todos os pensadores anteriores é a problematização radical dos princípios de identidade e contradição, pondo radicalmente em questão a preeminência tradicionalmente atribuída à identidade sobre a contradição" (FOUGEYROALLS, 1964, pp.191-2). Contudo, é difícil concordar inteiramente com esse diagnóstico. Se Hegel encarou a negatividade, a contradição a fundo, como sem dúvida o fez, não se deteve nela em sua radicalidade. De fato, não chega a ocorrer uma valorização tal do negativo que colocasse em questão a primazia da identidade. Por mais distante que esteja, Hegel ainda se move num solo onde a supremacia platônica da Ideia se faz presente. De um modo ou de outro, a organização da caoticidade do real tende a um fim harmonioso e idêntico. Para mostrar, contudo, como isso se dá, é preciso pensar a concepção de totalidade em Hegel.

A concepção hegeliana de negatividade não pode ser separada de sua faceta positiva. "Hegel quer superar um entrave na Metafísica, sem abandonar, entretanto, o ideal metafísico da identidade" (BORNHEIM, 1971, p.149). Como isso se dá? Na exata medida em que a totalidade está presente em cada momento da negação. Se a negatividade não possuísse positividade, colocaríamos como impossível uma exigência do próprio sistema hegeliano, isto é, a possiblidade da formação da consciência. "A série de figuras que a consciência percorre nesse caminho é, a bem dizer, a história detalhada da formação para a ciência da própria consciência" (HEGEL, 2016, p.73, grifo meu). Não é possível pensar em formação da consciência, desenvolvimento ou necessidade do processo se não tivermos em mente a relação

\footnotetext{
${ }^{1}$ Algo fundamental deve ser explicitado. Não é o foco deste trabalho por frontalmente a filosofia de Sartre num diálogo direto com Hegel bem como travar as instigantes batalhes teóricas de Sartre com Freud, por exemplo. Não será nosso foco mostrar, detidamente, como Sartre lê as especificidades da totalidade e da reconciliação hegeliana em profundidade, o que seria outro longo trabalho, nem como Sartre pode criticar os pressupostos da psicanálise freudiana como má-fé, uma vez que deturbam, pela inserção de determinações, a liberdade fundante do homem. Nosso esforço aqui é indicar possíveis apropriações da noção de negatividade nos presentes autores, e ainda que um confronto direto entre eles seja evidentemente elaborado de modo interno às suas filosofias, e, portanto, algum nível de relação será necessário, não faremos esse confronto de modo exaustivo.
} 
entre negação e totalidade. Pontua Hyppolite: "no lugar de apresentar o saber do Absoluto em si e para si, Hegel considera o saber tal como este é na consciência, e é precisamente desse saber fenomênico, a criticar-se a si mesmo, que ele se eleva ao saber absoluto" (HYPPOLITE, 2003, p.20, grifo meu). A própria ideia de elevação, desenvolvimento "das séries de figuras", seria incompreensível sem uma imanência do todo nas partes. Se a fenomenologia "é o itinerário da alma que se eleva ao espírito pelo intermédio da consciência" (HYPPOLITE, 2003, p.27), será preciso refletir sobre a necessidade desse processo, sobre a rede de conexões e encadeamentos que tornam possível a elevação. A negatividade é positiva, nesse sentido, pois comporta não o nada, não-ser simplesmente, mas uma determinação que eleva, através das sucessivas experiências da consciência, à ciência. "A experiência aparece para a consciência como uma descoberta de novos mundos, e isto assim ocorre porque esquece seu vir-a-ser... só vê o resultado negativo de sua experiência anterior" (HYPPOLITE, 2003, p.41).

Se a dúvida desesperadora se apresenta à consciência a cada nova experiência que destrói, na efetividade do mundo, sua verdade, nós, filósofos que somos capazes de compreender o sentido de cada estágio ${ }^{2}$, percebemos, contudo, a positividade de cada experiência negativa. É assim porque a negação não leva ao nada vazio, mas a uma determinação que a consciência engajada na experiência não é capaz de perceber. Pontua Hegel que "a série completa das formas da consciência não real resultará mediante a necessidade do processo e de sua concatenação mesma" (2016, p.73). A contradição se apresenta como negatividade que destroça as certezas de cada figura da consciência, mas isto não quer dizer que não haja necessidade no processo, ou que a negatividade seja o ponto final. Pelo contrário, não perceber a determinação dessas sucessivas negatividades é, justamente, para a consciência, seu desespero, não compreender a positividade de cada estágio. ${ }^{3}$ Fica estabelecido assim que "negatividade e totalidade se pressupõem reciprocamente em Hegel. Sem a negatividade, o todo não se põe, mas se o todo não é imanente em cada negação, tampouco a negatividade se efetiva de maneira determinada, isto é, positivamente" (REPA, 2011, p.275). Isto nos leva inequivocamente a perceber que se Hegel dera atenção à negatividade, não foi com outra intenção que superá-la. Por último "Para fazer inteligível esse ponto, pode-se notar previamente, de maneira geral, que a apresentação da consciência não verdadeira em sua inverdade não é um movimento puramente negativo" (REPA, 2011, p.73, grifo meu). Se inovador em relação à tradição, o filósofo ainda segue em busca da identidade plena, onde as contradições, não só da razão, mas do próprio real serão resolvidas. Em Hegel, "por eminente que seja a força da contradição, não é lícito afirmar-se, sem mais, que divirja de seus antecessores, realmente, não chega a haver uma preeminência absoluta... da contradição sobre a identidade" (BORNHEIM, 1971, p.149). Se permanece a encarar a negatividade nos olhos, não é senão para ultrapassá-la. Não há dúvida que o "trabalho do negativo" é uma reflexão poderosa em Hegel, contudo, é difícil defender uma ontologia do finito, por assim dizer, no hegelianismo. Hegel mergulharia na contradição para submergir na identidade.

Como um exemplo da maneira como a negação determinada ${ }^{4}$ opera no interior das experiências da consciência à revelia de seu conhecimento, basta lembrarmos dos vários momentos do processo formativo da consciência, como a certeza sensível que entra em contradição consigo mesma na exata medida em que, seguindo seu

\footnotetext{
${ }^{2}$ Ainda que este sentido, na acepção forte do termo, só possa ser compreendido no final de todo processo.

3 “A fenomenologia de Hegel é, por seu turno, o romance de formação filosófica: segue o desenvolvimento da consciência que, renunciando ás suas conviçcões primeiras, atinge através de suas experiências o ponto de vista propriamente filosófico, aquele do absoluto" (HYPPOLITE, 2003, p.28).

${ }^{4}$ Sem dúvida um dos aspectos mais fundamentais da dialética hegeliana. Não excluindo as concepções de Crítica Imanente, ou Experiência, que também são indispensáveis, aqui, se manterá o foco na negação determinada.
} 
critério de verdade previamente estabelecido, vai à efetividade do mundo testá-lo. Procura decretar este critério na colocação da essencialidade do conhecimento no objeto. "O saber que, de início ou imediatamente, é nosso objeto não pode ser nenhum outro senão o saber que é também imediato - saber do imediato ou do essente... a certeza sensível aparece como a mais verdadeira, pois do objeto nada ainda deixou de lado, mas o tem em toda a sua plenitude, diante de si" (HEGEL, 2016, p.83). O objeto da certeza sensível, índice de certeza, está posto e ao apontá-lo, a fim de captar o conhecimento do imediato, a certeza sensível insere aquilo mesmo que negara: a universalidade. Pois esta "mediação" posta pela própria linguagem, "isto aqui é noite", é já universalizar a imediatez.

Se digo que é noite ou que essa mesa é preta emprego nomes que designam qualidades e que supõe comparações, as quais introduzem uma mediação nesse saber. A noite ou o preto não convém somente àquilo que experimento imediatamente, mas designam ainda outras noites e outros objetos pretos. (HYPPOLITE, 2003, p.100)

Esta imediatez, assim, é o absolutamente singular, "isto", aqui e agora. Eé justamente nessa imediatez máxima, a procura deste "isto" singular, que a consciência fracassa. Pois ao dizer "agora é noite "ou "agora está frio", etc. a consciência não faz, senão, negar o próprio critério de verdade que ela mesma supunha e introduzir o ser-outro da imediatez: sua universalidade.

Enunciamos também o sensível como um universal. O que dizemos é: isto, quer dizer, o isto universal; ou então: ele é, ou seja, o ser em geral. Com isso, não nos apresentamos, de certo modo, o isto universal ou o ser em geral, mas enunciamos o universal: ou por outra, não falamos pura e simplesmente tal como nós o "visamos" na certeza sensível. (HEGEL, 2016, pp.85-86)

A mudez seria a alternativa. Não poder dizer seu objeto, que é a essência, sob risco de negar aquilo mesmo que buscava. O universal assim, condição da própria linguagem, emerge como ser outro da singularidade. Surge um conflito desesperador. A certeza sensível, tal qual todas as figuras subsequentes, pela negação radical de seu ser outro ${ }^{5}$ - condição da identidade no sentido forte para Hegel - não poderá obter sua verdade, suprimir-se-á dando lugar a uma nova figura da consciência, com outro critério de verdade, outra maneira de recorrer à efetividade do mundo para testar seu conhecer e, novamente, outra negação radical do ser outro que, sabemos, a engendra.

O que interessa salientar é que essa experiência é dramática para a consciência engajada no processo, puramente negativa. ${ }^{6} \mathrm{Sem}$ se dar conta que o próximo estágio de seu vir-a-ser é determinado pela negatividade da experiência anterior, a consciência mergulha no nada e no desespero, não vê a positividade na negação. ${ }^{7}$ A visão que a consciência tem da negatividade não é determinada, não possui nenhuma positividade, não há ser na contradição. A cientificidade e a necessidade do processo

\footnotetext{
5 “O falar tem a natureza divina de inverter imediatamente o visar, de torna-lo algo diverso, não deixando assim aceder à palavra" (HEGEL, 2016, p.92).

6 “Talé, aliás, o sentido usual da palavra 'experiência'. Na experiência, a consciência vê desaparecer algo de novo que a ela se opõe, um objeto. Porém, para a consciência filosófica, tal objeto (Gegenstand) é engendrado, ela vê nascer do movimento anterior (Entstandenes), ao passo que a consciência fenomênica esquece tal passado. Ela sempre recomeça a cada experiência, como se nascesse de novo" (HYPPOLITE, 2003, p.41).

${ }^{7}$ Não há espaço aqui, mas é importante ressaltar que essa experiência pela qual passa a consciência neste estágio, encaminha a uma mudança da posição da essencialidade. Se a singularidade máxima não é alcançada no visar do objeto singular, que era essencial, deve ser essencial então o Eu que apreende tal objeto. Esta mudança, porém, só é compreensível, se a vemos como resultado da falência anterior. Toda negação é negação determinada daquilo que resulta.
} 
estão vedadas a ela. ${ }^{8}$ Desse modo, da primeira figura até o saber absoluto, o processo é conduzido necessariamente pela negatividade. O sistema hegeliano pode ser visto como uma feroz totalidade imanente que não deixa restos. Assim como a linguagem lança a certeza sensível para além dela, também cada figura experimentará, em suas respectivas determinações e critérios o fracasso diante da efetividade do mundo. "Porém, quando o resultado é aprendido como em verdade é - como negação determinada -, é que então já surgiu uma nova forma imediatamente, e se abriu na negação a passagem pelo qual, através da série completa das figuras, o processo se produz por si mesmo" (HEGEL, 2016, p.74).

Nesse sentido, podemos concluir essa parte com a colocação de que Hegel, não só fiel à tradição em certo sentido, é o seu representante maior. O final do processo, o Absoluto hegeliano, se é verdade que fora engendrado por uma negatividade determinada que possibilitou o desenvolvimento e a formação da consciência, não podemos perder de vista, contudo, que tais negatividades são momentos a serem superados. A identidade total entre conceito e coisa nos coloca a reconciliação ao fim do processo, a cisão, tão arduamente experimentada, a contradição interna tão desesperadamente sentida pela consciência, ao fim deverão ser silenciadas. É por isso que se Hegel, de fato, olhou a contradição e a negação nos olhos, não podemos dizer que nelas permaneceu.

A cisão insuperável: Sartre e a absolutização do negativo.

A fenomenologia do espírito é a viagem do espírito em busca de si mesmo. Ela começa com o saber sensível e mais imediato e abstrato e culmina com o saber absoluto... É preciso não só passar por todos os momentos, mas também permanecer neles pois cada momento é uma figura que só se deixa apreender em sua totalidade. (SANTOS, 1993, p.74)

Desta totalidade ${ }^{9}$, que já vimos, apresentando-se em cada negação determinada, na dialética hegeliana, interessa-me ressaltar o caráter reconciliador. No fim do processo, a cisão como problema amplo que vem incomodando a filosofia, há de ser suprimida. É aqui que Sartre surge como um dos exploradores do que podemos chamar de fissuras abertas no absoluto, onde um dos expoentes pode ser visto também em Kierkegaard. Para Sartre, a existência individual será irredutível e angustiada, sem um processo de formação rumo a um estado reconciliador. Se hegeliano em muitos sentidos, como nas expressões que utiliza ${ }^{10}$, Sartre difere profundamente de Hegel. A negatividade pensada pelo francês é radicalmente outra.

O ponto de partida de Sartre é a subjetividade individual, e "por razões estritamente filosóficas" (SARTRE, 2014, p.33) ele permanecerá fiel a essa verdade cartesiana até o final. "Fora desse cogito cartesiano, todos os objetos são apenas prováveis... para definir o provável é necessário possuir o verdadeiro. Portanto, para que exista uma verdade qualquer é preciso uma verdade absoluta" (SARTRE, 2014, p.35). Esta verdade só pode residir na subjetividade. "A necessidade de afirmar a consciência como primeiro princípio impõe-se a Sartre com força de evidência, e não existe em sua obra a tentativa de problematizar essa exigência que surgiu, como é notório, com a metafísica moderna" (BORNHEIM, 1971, p.14). Ora, com o alicerçar-se nesse

\footnotetext{
${ }^{8}$ Ponto central para melhor pontuar essa colocação é considerar a crítica imanente. Aqui, não há espaço para melhor pontuar este importante conceito hegeliano, basta que se tenha claro que não é necessário ao filósofo que "interfira no sentido" observado, acrescentar nada à consciência sensível, ao contrário, os próprios critérios que esta consciência coloca mostrar-se-ão impossíveis de serem alcançados. O ser-outro, negatividade, surgirá de dentro da própria consciência em suas múltiplas figuras.

${ }^{9}$ Não se pretende dizer que Sartre não possua uma consideração à totalidade. Ao contrário, este conceito é fundamental quando das análises sartreanas na Crítica da Razão Dialética, e a possível atenção à História dada nesta obra. Aqui, intenta-se apenas demonstrar as divergências das acepções no que concerne a ideia de reconciliação vinculada à totalidade.

${ }^{10}$ Exemplos são “Em-si”, “Para-si", "Ser-para-outro", "negatividade”, as análises sobre o “Olhar do outro", etc.
} 
ponto, inevitavelmente, as consequências a que chega o próprio Descartes também estão presentes. A separação sujeito-objeto põe-se como fato, mas para Sartre, essa dicotomia apresentar-se-á imediatamente numa dimensão ontológica sem recurso a Deus como vínculo possível entre a materialidade do mundo e a representação que há no sujeito. Cabe já, assim, pontuar que também um processo rigorosamente necessário engendrado pelas negações determinadas não poderá terminar numa reconciliação, identidade entre sujeito e objeto, como em Hegel. Para Sartre, contudo, não será preciso se debater para resolver o problema dessa cisão, ele admite prontamente a irredutibilidade dos dois reinos: a subjetividade e o reino da matéria. "Realmente afirmada a precipitude do cogito, não há como fugir ao dualismo" (BORNHEIM, 1971, p.15).

Mas uma diferença fundamental com Descartes se coloca. Se este, no processo de suas Meditações, servira-se da dúvida metódica e radical numa dimensão epistemológica, o caráter desta dúvida em Sartre será mais largo. É a existência humana em sua necessidade que será posta sobre suspeita. E se assim o é, como Sartre demonstra em seu romance A Náusea, de 1938, o caráter existencial da dúvida cartesiana se apropriará da consciência para jamais abandoná-la. Mais uma vez acompanhamos uma radicalização fundamental: a gratuidade da existência através da facticidade de existir simplesmente é já uma experiência negativa profundamente distinta das construções hegelianas. De fato, o desespero pela dissolução de sua verdade acompanha cada drástica experiência das figuras da consciência, elas perdem sua verdade. Mas a experiência narrada por Sartre, em suas investigações ontológicas, não nos permitirá sair desta situação. A dramaticidade existencial do absurdo da existência é preservada. É claro que caberia falar sobre o que vem a ser a experiência da náusea como a nadificação dos sentidos do real, onde tudo aparece como demais, e a consequente descoberta da gratuidade, contingência de tudo o que existe, mas, infelizmente, aqui não teremos tempo. O importante é compreender o papel da negatividade dessas experiências. No plano ontológico, a irredutibilidade dos dois reinos e a afirmativa da gratuidade da existência só podem ter consequências radicais. $\mathrm{O}$ absurdo da existência, progressivamente experimentado por Roquentin ${ }^{11}$, leva-o a constatar a não necessidade do real, e nada pode explicar ou justificar aquilo que existe. A negatividade máxima dessa situação é expressa nas palavras finais do romance: "Todo existente nasce sem razão, prolonga-se por fraqueza e morre por acaso" (SARTE, apud BORNHEIM, 1971, p.22). Dessas breves linhas, não se extraia, contudo, que a preocupação com o fundamento não seja uma constante em Sartre. O real, ainda que gratuito e contingente, ainda o é ${ }^{12}$. E isso coloca Sartre no núcleo da tradição metafísica, num franco diálogo com Hegel, isto é, procurar o fundamento do existente. Mas se os dois reinos não podem ser confundidos, Sartre haverá de precisar qual o fundamento de cada um deles.

"O pensamento moderno realizou o progresso considerável ao reduzir o existente à série de aparições que o manifestam" (SARTRE, 2016, p.15). O que aparece constitui-se como fenômeno, e Sartre inicia a primeira parte de sua Ontologia Fenomenológica à procura do fundamento dessa realidade contingente. Estabelecida a dualidade, Sartre não pode aceitar, como veremos, a resposta kantiana da subjetividade como polo organizador do diverso fenomênico, e assim o fundamento deve ser buscado na própria coisa. Categoricamente, Sartre reduzirá o ser do fenômeno a seu aparecer.

\footnotetext{
${ }^{11}$ Protagonista do romance A Náusea.

${ }^{12}$ Cabe uma consideração importante. Seguindo Heidegger, Sartre, embora aceite a formulação da primazia da subjetividade, considera que o mundo se manifesta como algo evidente. Utilizando da expressão heideggeriana "ser-no-mundo", Sartre compreende esta subjetividade absorvida no real, a consciência é imediatamente aberta ao mundo. "É o homem no mundo, com essa união específica do homem com o mundo que Heidegger, por exemplo, chama de "ser no mundo" (SARTRE, 2016, p.43). Se o ponto de partida é a consciência, não é, contudo, fechada.
} 
O que o fenômeno é, é absolutamente, pois se revela como é. Pode ser estudado e descrito como tal, porque é absolutamente indicativo de si mesmo... Tudo está em ato... a essência de um existente já não é mais uma virtude embutida no seio desse existente. (SARTRE, 2016, p.17)

Derrubadas as distinções clássicas da filosofia, como ato e potência, substância e acidente, o fenômeno nada possui atrás de si, a aparência nada esconde, ela é a essência. O Fenômeno esgota-se completamente em seu aparecer.

Confrontemos os dois autores novamente quanto à negatividade. Se Hegel nela se aprofunda, é para que a reconciliação final venha suprimi-la. Em Sartre vemos outra acepção do negativo. Nas palavras de Sartre " ...há em Hegel outra forma de otimismo, mais fundamental. É o que convém chamarmos de otimismo ontológico. Para ele, com efeito, a verdade é verdade do Todo. E Hegel se coloca do ponto de vista da verdade, ou seja, do Todo" (SARTRE, 2016, p.315). Contraposto à experiência da totalidade como reconciliação, Sartre nos fala da experiência do homem lançado ao mundo sem por quê, habitando entre fenômenos fechados e esgotados em seu aparecer, "contingente e absurdo", este homem, ainda que difira daquilo que vê, não se sabe como justificativa e tampouco simples efeito. A experiência que em Hegel transforma completamente a consciência, e logo, seu objeto, mas que é guiada numa negatividade determinada que engendra um processo "ascendente", ainda que ela não saiba, em Sartre, é como se esta mesma experiência de angústia sentida pela consciência não pudesse caminhar para a reconciliação. Se podemos, sem problemas, dizer que tanto Hegel quanto Sartre pensam o problema da contradição pela identidade, o primeiro, contudo, possibilita a resolução absoluta da questão, enquanto o segundo tornará este "tender para o idêntico" um fracasso insuperável. Mas isto só se torna compreensível se explicitarmos, para além da negatividade da própria descoberta da Náusea, o fundamento do Eu, ou, em linguagem Sartreana, do Para-si.

O título de seu ensaio ontológico já nos indica o solo em que se move Sartre. Trata-se do ser, mas também do nada. Ora, o ser é o em-si, mundo material, os objetos, aquilo mesmo que se esgota em seu aparecer. Seu fundamento radica em ser o que é, sem potencialidades ou fissuras. Vimos já que

Sartre quer evitar a cisão, de tipo kantiano, entre ser e fenômeno, e o subsequente abandono do fenômeno a si mesmo... se trata de uma concentração no finito, nisso que está aí, com clara intenção de reconquistar para o fenômeno um estatuto ontológico. (BORNHEIM, 1971, p.29)

Se o ser é o em-si, opaco, idêntico a si mesmo ${ }^{13} \mathrm{e}$, se, todavia, Sartre estabelece uma dualidade radical pela primazia conferida à subjetividade, resta então a pergunta: 0 que é a consciência já que radicalmente outra que não o mundo? Ela só poderá ser nada. Mas se o em-si é totalmente outro que não a subjetividade, e se o ser é o em-si, como determinar esse nada? Como apreender a negatividade da consciência já que, se é nada, não se lhe pode haver ser? É aqui que podemos dizer que Sartre conserva-se no negativo e o torna absoluto. Sem fim reconciliador, o absoluto é a negatividade intrínseca à definição do que seja a própria subjetividade humana. A última peça dessa equação desvela-se na concepção da consciência como intencional.

Toda consciência, como notou Husserl, é consciência de alguma coisa. Significa que não há consciência que não seja posicionamento de um objeto transcendente, ou, se preferirmos que a consciência não tem "conteúdos"... O primeiro passo de uma filosofia deve ser, portanto, expulsar as coisas da consciência e restabelecer a verdadeira relação entre esta e o mundo, a saber, a consciência como consciência posicional do mundo. Toda consciência é posicional na medida em que se transcende para alcançar um objeto, e ela se esgota nessa posição mesma: tudo quanto há de intenção na minha consciência atual está dirigida para o exterior. (SARTRE, 2016, p.22)

13“O em-si não tem segredos, é maciço” (SARTRE, 2016, p.40). 
Em Sartre, "a consciência em sua natureza mais profunda é relação a um ser transcendente" (BORNHEIM, 1971, p.29). Dotada de caráter ontológico, a intencionalidade em Sartre surgirá no centro nas análises da subjetividade. ${ }^{14}$ A consciência, não passando de um vazio transparente, alimenta-se de sua intencionalidade: estar consciente é, sempre, estar consciente de alguma coisa. Ora, a consciência visa ao mundo, percebe-o, desliza para, mas se sabe radicalmente outra que não ele, o fundamento é o ser, o idêntico, presença "maciça", a consciência assim é nada, é movimento para, tender a, vazio. A radicalidade da experiência negativa é assim elevada à condição existencial permanente. Trazida para dentro do Para-si, que é nada, a negatividade, a contradição, é a condição primeira da consciência. Cisão definitiva, a consciência desliza para o mundo, mas na percepção desse mundo, já se sabe outra que não o ser. A própria realidade humana é caracterizada como um absurdo, a consciência está condenada a "ser o que não é e não ser o que é". ${ }^{15}$ Se o fundamento se transforma justamente nessa solidão radical do em-si, ser com força máxima, este mesmo em-si é inerte, cabendo à consciência, que é deslizar para ele, perceber-se por meio desse outro, que não ela, o que ela é: Nada.

A consciência é consciência de alguma coisa: significa que a transcendência é estrutura constitutiva da consciência, quer dizer, a consciência nasce tendo por objeto um ser que ela não é. Chamamos isso de prova ontológica... dizer que a consciência é consciência de alguma coisa significa que não existe ser para a consciência fora dessa necessidade de ser intuição reveladora de alguma coisa, quer dizer, um ser transcendente. (SARTRE, 2016, p.34)

O fundamento, assim, não reside no fim de um processo dialético, como em Hegel, mas está emperrado no início, sem possiblidade de instaurar uma negatividade positiva. ${ }^{16}$ "Embora Sartre afirme que o fundamento do Para-si está no em-si, tal fundamento não chega a ter vigência; se os termos permanecem exteriores, é porque se recusa, de saída, qualquer possiblidade de síntese" (BORNHEIM, 1971, p.159). Tudo na ontologia sartreana se move no solo do "tender", sem, contudo, fugir ao nada.

Se é verdade que sem a radicalidade da metafísica hegeliana é quase impossível compreender as concepções sartreanas, que continuam se movendo nesse solo, todavia, a presença reconciliadora da metafísica propriamente dita não se realiza metafisicamente em Sartre. "A separação é devolvida a si própria" (BORNHEIM, 1971, p.163). É como se o movimento de participação, importante conceito platônico, por meio dos sucessivos "desejos de ser" da consciência não conseguissem repousar na identidade. A participação se vê reduzida ao deslizar da intencionalidade, e esta como esforço contínuo e inacabado. A consciência se sabe outra que não o que intenciona, nada a justifica, assim como nada a vincula essencialmente a um seguro repouso ontológico. Angústia e finitude permanentes, eis o quadro sartreano do homem.

\footnotetext{
${ }^{14}$ Vale pontuar que este conceito de intencionalidade é justamente o que vai possibilitar o ser objetivo do fenômeno. A estrutura intencional da consciência, desse modo, não fundamenta ontologicamente o em-si, todavia, sendo "essencialmente" intencional, sabe-se no ato de não ser aquilo que percebe. "A consciência nasce conduzida por um ser que não é ela mesma" (SARTRE, 2016, p.30).

${ }^{15} \mathrm{O}$ projeto de esvaziamento da subjetividade é uma constante na obra de Sartre, e desde seu artigo sobre a Intencionalidade, passando pela Transcendência do Ego e os ensaios sobre psicologia, na obra "O ser e o nada", radica sua visão ontológica. Não é o foco aqui, contudo, desdobrar as consequências radicais do esvaziamento subjetivo para as concepções de liberdade, projeto, má-fé, e etc.

16“A procedência da existência sobre a essência não me impede de almejar uma essência, ao contrário até me levam a isso. Na verdade, o que eu gostaria mesmo é que minha escolha redundasse numa metamorfose: uma nova forma... quero simplesmente ser na forma do Em-si, mas sem perder a consciência de si, isto é, sem deixar de ser Para-si... Se o Para-si se realizasse no seu ser em si ele se perderia. Mas é precisamente isso o que o existente almeja: perder-se para realizar-se, perder-se para ganhar-se, "perder-se para fundamentar o ser", o próprio ser e assim escapar à contingência" (SILVA, 2004, p.27).
} 


\section{Freud: a marginalidade do eu e a ascensão de uma queda.}

Sem a terminologia ontológica, Freud do mesmo modo nos oferece um sujeito cindido à sua vontade, alheio a seu processo de funcionamento e ciente apenas daquilo que através de sucessivas transformações e esforços pode ascender à "superfície" da atividade mental. Por vias outras que não a investigação fenomenológica de cunho ontológico empreendido por Sartre, o psicanalista vienense também nos oferece um homem em crise perpétua; irredutível dimensão pulsional, dispersividade constituinte e saudoso de um reencontro. Freud também é um pensador que radicaliza uma concepção de homem no seio da cisão sem um futuro de positividade plena. A psicanálise enquanto discursividade (FOUCAULT, 2014) se erige justamente na percepção da insuficiência do discurso totalizador que se manifesta na tradição fundacionista (FIGUEIREDO, 2015), para dar conta da problemática do sujeito e da autonomia da razão. Se é verdade que a centralidade, mesmo uma atividade sintética do Eu (KANT, 2012), da consciência é problematizada pela psicanálise, também o é que a finitude, enquanto negatividade encarnada na experiência mesma da subjetividade cindida, é pressuposto do pensamento freudiano. A experiência negativa em Freud busca uma síntese que englobe as vicissitudes da dispersividade pulsional, na tentativa de compreender ao máximo os processos pelos quais a subjetividade se torna o que é. Mas, distintamente a Hegel, não haverá uma síntese final: o sujeito será sempre cindido.

Como Freud caracteriza a dimensão da natureza e ao mesmo tempo como compreende a cultura em sua função protetora nos será de grande interesse. A civilização pode ser resumida em suas funções, de modo bastante geral, mas acertado, em duas atribuições fundamentais (FREUD, 2014). Ela nos protege contra a natureza e contra o próprio homem. Quanto à primeira, coube aos desenvolvimentos da técnica e da ciência o controle do reino natural. Às instituições, que podem ser vistas como reguladoras da relação homem-homem, coube a segunda função. Mas as coisas não são tão simples. Pois se a cultura continua sendo a grande defensora dos homens contra a natureza (FREUD, 2010c; 2014; 2010a.), e, se esta desdobra-se em muitos caminhos (os poderes irrestritos das catástrofes, o cruel poder do destino, e mesmo a pulsionalidade inata que assombra o convívio) não podemos facilmente equacionar natureza e violência de um lado e civilização e paz de outro. As coisas não são tão simples porque mesmo na sua função protetora, o que permite mesmo a vida na terra se desenvolver na chave tipicamente cultural, a cultura ${ }^{17}$ também carrega uma fortíssima dose de violência e traz sérios infortúnios ao homem. A civilização também mobilizará recursos para englobar de maneira mais abrangente possível os reveses da natureza (mesmo a humana), mas, para fazê-lo, ela marca duramente a humanidade. Para que seja possível a convivência entre os homens, e sem perdermos de vista a incessante pulsionalidade que exige satisfação irrestrita, é preciso a lei, as normas que regularão nossa convivência. Ganha-se a segurança da lei, é verdade, mas uma lei introjetada, a lei vigia de si, a lei do pai como castradora da expansão do próprio corpo. No limite, não fugimos à violência: mudamos o polo de ação. Do mundo para dentro, somos a violência desde o início. Mas como se dá essa passagem? Será preciso, brevemente, destacar a formação da subjetividade humana e como a presença da violência civilizatória está, desde o início, posta em primeiro plano.

É a possiblidade inaugurada pela obra de 1914, Introdução ao Narcisismo, acerca do Ideal do $\mathrm{Eu}^{18} \mathrm{como}$ "parte" inconsciente em atividade no seio da subjetivada que nos

\footnotetext{
${ }^{17}$ Tal qual Freud explicita, acerca de seu próprio uso, em O Futuro de uma ilusão (2014, p.233) os termos Cultura e Civilização serão aqui usados de modo equivalentes.

${ }^{18}$ Não acompanharemos o tortuoso caminho que levará das formulações do Ideal do Eu de 1914 até a noção de Super-Eu em 1923. O que precisamos para argumentação é apenas destacar que há uma instância no interior do próprio sujeito que, trazendo as faces da civilização - pais, educadores, leis, normas... - determina as possiblidades da subjetividade de modo inteiramente alheio à própria vontade do sujeito.
} 
faz compreender a "dissecção da personalidade psíquica" (FREUD, 2010b) em mais complexidade. Será preciso considerar os longos anos de dependência do infante, impotência absoluta como primeira chave dessa caracterização. Nesse contexto, a relação estruturante dos pais como objetos de proteção e amor, aqueles a que se deve a própria dimensão da satisfação inicial ${ }^{19}$ bem como o medo constante de sua perda será também fundante. Em terceiro lugar há um aparelho mental ainda em construção e, consequentemente, um Eu frágil e ainda em pedaço ${ }^{20}$, eis o solo fértil para as marcas da cultura na subjetividade. A lei antes exterior - e aqui o golpe ao kantismo é evidente - através de mecanismos de introjeção e identificação passa a ser lei interna: o nascimento do imperativo categórico é, em essência, violento. Por medo de perder o amor daqueles que o guiam, o infante se submete à lei. O contrato, numa entre muitas das vertentes freudianas, é o pacto inconsciente a um pai soberano porque integrante da subjetividade. Cultura, norma, regulação, educação, ideal, pais: os paranoicos, em uma de suas queixas clínicas mais insistentes, tinham mesmo razão, algo está nos observando. Mas de dentro, pontua Freud (FREUD, 2010a, 2011, 2010b).

Para além dessa tragicidade inicial, resta a pergunta: mas pode mesmo a cultura salvar-nos da mazela? Se a civilização, mesmo com seus reveses - isto é, forte dose de violência na modelagem do sujeito humano que, por fragilidade e dependência, submete-se a ela - é fundamental na proteção contra a natureza e contra os próprios homens, a experiência da angústia e do desespero permanecerá insistentemente presente. Isto manifesta-se claramente numa dura reflexão: a morte será sempre um dado incômodo à espécie humana. Freud o sabia, repetiu inúmeras vezes: suportar a morte segue sendo a tarefa primeira da vida (FREUD, 1915). Contra a mazela do fim, da limitação de si, da morte como símbolo universal da impotência não há saída. Nem estado, nem cultura, nem lei. Morreremos.

É deste ponto, entre tantos outros que não trataremos aqui, que as análises interpretativas para a função e mesmo a fundação da religião partem. Por que há inabalável força na religião? Pela capacidade de oferecer saída ao que a cultura não pode: a morte, a dor, a negatividade (des)encarnada. Se a lei regula as relações do difícil convívio, impedindo a expressão da pulsionalidade através dos olhos de dentro, a natureza imperiosa nos marca com a conscienciosidade da morte. Eis o desamparo humano escancarado em cada amanhecer. Por isso, Freud pode sustentar até o fim da vida que o sentimento religioso parte de um desamparo universal (FREUD, 2014). Na obra O Mal-Estar na Civilização, de 1930, muitos caminhos são dados para suportar a cultura, suportar as privações da vida civilizada. Mas, pergunta-se Freud, como fugir da natureza que, em certo sentido, sempre nos escapará?

A cultura o dispensa dessa tarefa, executando-a para todos igualmente, e é notório nisso, que quase todas as culturas ajam da mesma forma. Ela não cessa de realizar sua tarefa de proteger o homem contra a natureza, ela a continua por outros meios. A tarefa é múltipla, a autoestima gravemente ameaçada do ser humano exige consolação, o mundo e a vida devem ficar livres de pavores, e além disso, a ânsia de saber humana - impelida, é verdade, por fortes interesses práticos - também pede uma resposta. (FREUD, 2014, p.248)

\footnotetext{
${ }^{19}$ Não há interesse aqui em determinar de maneira precisa as fases da libido bem como das organizações erógenas que se sucedem para a maturação do indivíduo sexuado. Apenas se focaliza que a dimensão do outro que não o mesmo é fundamental para compreensão dos processos iniciais da sexualidade humana. A balança narcisismo e relação objetal não precisa ser aqui dissecada para que seja tornado explícito que os laços entre criança e mãe é fundamental para a força introjetada da civilização, não só pelo medo da perda do objeto e amor (o que facilita a introjeção) bem como a formação dos ideais através dessa relação de fortíssima carga.

${ }^{20} \mathrm{~A}$ aproximação com a construção da subjetividade nos dois autores precedentes já aqui começa a esboçar diálogo, pois este Eu em formação, sede máxima da discursividade filosófica clássica, em Freud não poderá ser completamente totalizado ou totalizante. No limite, este despedaçamento permanecerá constante.
} 
A cultura poderá dar essa resposta oferecendo a religião. Mas para que esta religião se dê vejamos algumas anterioridades. No início ${ }^{21}$, a estratégia dos homens fora "humanizar a natureza" (FREUD, 2014, p.248). Se a natureza temida puder ser vista como animada pelas mesmas forças espirituais dos homens, se houver alguma relação, então a natureza pode ser "domada". As análises de Totem e Tabu abriram o campo para tal: troca-se a lei natural pela psicológica. O mundo natural é regulado pelas mesmas regras dos homens. Se o rio, o ar, o fogo, o sol são entidades vivas, elas podem ser influenciadas. Entenda-se: trata-se de barganhar com a natureza, modificar seu curso através da crença nos próprios pensamentos (FREUD, 2013).

Se nos elementos as paixões se agitam como no interior da própria alma, se nem sequer a morte é algo espontâneo, e sim o ato violento de uma virtude maligna, se em toda parte, na natureza, o indivíduo está rodeado de seres tais como os que conhece da própria sociedade, então ele respira aliviado, sente-se em casa num meio inquietante, pode elaborar psiquicamente a sua angústia sem sentido. Talvez ainda esteja indefeso, mas não mais paralisado e desvalido, pode ao menor reagir; sim, talvez não esteja sequer indefeso, e possa utilizar, contra os violentos super-homens lá fora, os mesmos recursos que emprega em sua sociedade, tentando suplicar-se, aplacá-los suborna-los, tornando-lhes, assim parte do seu poder. (FREUD, 2014, pp.248-249)

Esta longa citação será desculpada pela riqueza da argumentação freudiana. Como se lida com a natureza no início? Converte-se a natureza em algo vivo da mesma maneira que são os homens. A observação da morte, o estado de sono e do sonho - afinal, dormindo o primitivo vê seus mortos queridos na mesma proximidade que Descartes via o fogo à sua volta - e a incapacidade de se convencer da própria morte: o desamparo diante ao mistério da existência é a raiz das produções místicas e religiosas. Trata-se, deixemos claro, de estabelecer uma maneira de barganhar com a natureza. Pois o mesmo fará a religião. O desamparo está presente, mas há a possiblidade de modificar o rumo das forças naturais pela força dos desejos humanos. Ele, o homem, respira aliviado não pelo desamparo em que vive, mas pela possiblidade de atribuir um sentido e um plano pragmático de ação. O narcisismo do homem - podíamos dizer, o princípio do prazer que não aceita desvios e quer a imediatez da satisfação - necessita ser recompensado pelas mazelas da natureza.

Mas, não percamos de vista: a experiência da finitude da vida, a experiência da violenta convivência entre homem e cultura, inclusive as drásticas batalhas do sujeito contra seu próprio Ideal internalizado que exige punições e angústias, são momentos de negatividade que, inclusive do ponto e vista clínico, exibem as mais drásticas formas de adoecimento psíquico. A religião, nesse sentido, é o remédio reconciliador que porá fim às contradições da vida. Mais uma vez estamos no solo hegeliano, isto é, a tendência à identidade é posta às claras: o "retorno a pátria eterna" é a saída do homem de sua experiência existencial tão terrível. Tal como Sartre, o homem freudiano está cercado de gratuidades e excessivas experiências angustiantes. Contenção da dor por um plano reconciliador, a civilização vê brotar no seio de sua estrutura a religião. Mas como isto é exatamente possibilitado?

A grande arma teórica que Freud nos oferecerá para possibilitar essa estratégia é dada pela ideia de regressão a uma fase anterior. Como pode a produção dos Deuses e ardis para tornar a existência mais calma, leve, ilusória? Freud explica: a situação de profundo desamparo e desespero não é nova para o homem. Na verdade, ele já esteve, cada um de nós, nessa mesma situação. Trata-se do desamparo infantil, dos longos anos de dependência parental. De modo que a situação narrada de desamparo frente ao mundo pode ser vista como uma continuação daquela anterior, primeira, primordial. Eis a chave para Freud:

\footnotetext{
${ }^{21}$ Trata-se do recurso comumente usado por Freud acerca das especulações da vida dos primitivos. A relação Freud-etnografia, bem como suas aproximações das análises mitológicas é complexa e não nos cabe aqui aprofundar a questão.
} 
De modo semelhante os indivíduos transformam forças naturais não simplesmente em indivíduos, com os quais pode lidar como faz com seus iguais - isso não faria jus à impressão avassaladora que elas lhe acusam - mas lhes dá um caráter paterno, transformando-as em deuses, e nisso segue um modelo... infantil. (FREUD, 214, p.249)

Trata-se assim de repetir uma situação já vivida. Trata-se da humanização da natureza com ares antropológicos o que possibilita estabelecer uma relação com ela, tal como fora possível entre criança e pais. O que ocorre em Futuro de uma ilusão, 1927, é que o desamparo se torna presente nos homens universalmente. E a partir dele, essa constatação árdua, inevitável e profunda, o psicanalista encaminha as maneiras de compreender a fuga desesperada da finitude. A negatividade é presente desde o início. Podemos dizer metaforicamente que na primeira experiência de satisfação quando do nascimento o infante, ele ainda não havia, de fato, nascido. Alimentado, sem a menor sensação de desprazer ou necessidade. Mas logo este estado de equilíbrio se esmorece para sempre: a fome e outras sensações surgem e o grito é a única ação possível de expressão. Errôneo seria crer que o berro chama a mãe. Não há ainda a mãe ou o eu. Berra porque o berro é a única ação possível. Negatividade inscrita no desespero da necessidade que surge de "dentro". A primeira mamada é o fim da tensão, mas ela voltará. A pulsão é Constant Kraft (força constante), é drang (instar, impulsionar): incessante exigência. E no âmago da vida psíquica seremos sempre desamparados e temerosos diante da vida. A humanização da natureza pode ocorrer nos modelos dos pais porque já vivemos o mesmo desemparo e esta situação fora "resolvida" através da relação com eles.

Essa humanização da natureza irá gradativamente desaparecer, pois o desenvolvimento de formas mais sofisticas de acesso ao mundo físico bem como a observação das regularidades naturais vão eliminado a ideia de que por detrás das forças naturais há uma alma. Claro que Freud tem em mente a concepção científica e suas desmistificações. O problema é que o desamparo do homem não desaparece por isso. Pois pode ele cada vez mais controlar essa mesma natureza que antes temeu, mas quanto ao destino, à morte, e às relações humanas - a cultura -, ele não tem uma saída tão simples. Diríamos mesmo, quanto ao próprio atravessamento ininterrupto das exigências pulsionais. Enquanto se vive, finito, limitado, é infinita e ilimitada a potência pulsional: deslocada, sublimada, condensada; em sonho, no riso, no sintoma - somos a constante expressão daquilo que não se sacia nunca. O desejo segue sendo o motor do aparelho psíquico (FREUD, 1976), o que não quer dizer que esse movimento encontre repouso.

Eis o âmago do edifício religioso. Trata-se de ver que com o tempo, milenar sem dúvida, a humanização da natureza se desfaz e a figuração de um deus único acima da própria natureza é produzida, a própria função desse deus é ampliada. Trata-se agora de uma divindade mais pessoal e que pode auxiliar inclusive nos assuntos morais, e no destino humano. A mesma resposta é dada por Freud para essa possiblidade, o desamparo humano impulsiona-o para trás, e, tendo já vivido essa situação de miséria, ele projeta um pai grandiosamente elevado que o protege do destino e da morte. Mais do que isso, este deus pai elevado cumpre também a função mais importante do ponto de vista da cultura: oferecer recompensas às mazelas culturais. Isto significa que às drásticas experiências de finitude e desamparo, negatividades encarnadas na existência humana, a experiência religiosa vem oferecer o repouso à identidade onde a reconciliação finalmente suprirá a dor, o medo, a angústia, a própria natureza pulsional incessante do homem. Ainda mais, trata-se de uma providencia que conhece o coração do homem, sabe de suas agruras intimamente.

Essa providência o homem comum só pode imaginar como um pai grandiosamente elevado. Apenas um ser assim é capaz de conhecer as necessidades da criatura humana, de ceder a seus rogos e ser apaziguado por seu arrependimento. Tudo isto é tão claramente infantil, tão 
alheio à realidade, que para alguém de atitude humanista é doloroso pensar que a grande maioria dos mortais nunca se porá acima desta concepção de vida. (FREUD, 2010c, p.27)

Isto quer dizer que todo o sofrimento humano será finalizado num paraíso sem tensões e restrições. Onde, no limite, não haverá cultura, nem destino, nem a morte, e nem a intensidade violenta da agressão e da pulsionalidade. Fuga da violência do estado de natureza pelo recurso transcendente. Estas estruturas que tanto nos privam - externa e internamente - hão de silenciar. Suportar a vida segue sendo a tarefa mais difícil dos vivos, poderia bem dizer Freud.

Passa a ser tarefa divina compensar os defeitos e prejuízos da civilização, atentar para os sofrimentos que os homens infligem uns aos outros na vida em comum, zelar pelo cumprimento dos preceitos culturais a que os homens obedecem tão mal. As próprias normas culturais são tidas como de origem divina, são elevadas acima da sociedade humana, estendidas para a natureza e o universo. (FREUD, 2014, pp.250-251)

As próprias restrições tão severas passam a ser justificadas pelo edifício da religião. Quando os caminhos das normas, das leis, da proibição são justificados por Deus, basta defender esse patrimônio - cultura/religião - e sentir-se integrado, mesmo que seja integrado na coação. A pergunta com que Freud abre o capítulo III do Futuro de uma Ilusão é "em que reside o valor das ideias religiosas"? e temos aqui a resposta. Reside na possiblidade de salvar os homens do desamparo violento. Reside na possiblidade de aliviar a frustração cultural tão intensa; eliminar o destino cruel através da ideia de que, tal como o pai infantil que guiava as nossas ações, o destino irá se dirigir da melhor maneira possível - deus / pai sabe o que faz -, o seu valor reside justamente no poder reparador diante da ferida narcísica do homem: ele não é o centro do universo, ele morre, impotente. Reside, voltemos aos dois autores vistos, na segurança de um repouso ontológico que, necessário, desdobra-se em cada etapa do desenvolvimento da civilização e do sujeito. Reside, com Sartre, na sedutora possiblidade de dar ao Para-si uma participação efetiva no ser: silenciar a gratuidade e a dor.

Mas será mesmo que o destino pode ser sanado por essas figuras míticas com face paternal? Não seria o caso de ver que "persiste a desagradável suspeita de que a perplexidade e o desamparo humanos não podem ser remediados" (FREUD,2014, p.250), afinal, como pontuou o pensamento mítico grego, há Moiras que tecem o destino mesmo dos deuses. Seria o destino avassalador capaz de barrar a estratégica humana de se livrar da dor? Essa suspeita logo é eliminada. Engenhosos são os humanos talhados pela necessidade de fugir à negatividade. E aqui chegamos à mais elevada ideia da religião que nos reenviará a questão sobre a morte. A maneira como a religião pode lidar com o desamparo humano é deslegitimar essa vida de intenso sofrer e avassalador destino e prometer uma outra vida. É através desse recurso, a criação de outro lugar de repouso, que as mazelas do todo da cultura podem ser suportadas. ${ }^{22}$ Podemos mesmo dizer que todas as funções dos deuses

\footnotetext{
${ }^{22}$ Trata-se, evidentemente, de uma referência a todo edifício hegemônico da tradição filosófica ocidental. Muito bem analisada por Nietzsche, cabe ver que a tradição iniciada na filosofia de Platão com a separação moral entre alma e corpo - e ratificada pelo pensamento cartesiano na autonomia absoluta das esferas extensão e pensamento - está inserida exatamente nas problemáticas que Freud quer elucidar: o ponto focal é compreender que a vida se torna melhor, mais suportável, quando a vida é tornada pior, isto é, etapa, passagem. Trata-se da inversão proporcionada pela tradição do pensamento que, para suportar os descaminhos da vida, possibilita uma outra para sanar a ferida narcísica. O que Fred oferece como novidade para suas análises da depreciação da existência é, entre outras coisas, a repetição do modelo infantil reposicionando as mesmas peças que um dia já se apresentaram. Muitos comentadores insistem que a crítica freudiana da religião reside essencialmente na caracterização do cristianismo. Todavia, focalizando as dimensões aqui analisadas, isto é, direcionado a concepção freudiana para a estratégia de destruição da finitude e da vida terrena para a atribuição a uma outra vida, Freud possibilita estender a interpretação religiosa a campos muito mais vastos do que a religião monoteísta cristã. Se o ataque é essencialmente as estratégias utilizadas pelo edifício religioso, é plenamente possível - se não necessário - a extensão de sua interpretação.
} 
até aqui vistas podem ser unificadas no momento em que a vida mesma passa a ser diminuída. Se a própria morte não é o fim, então este estágio de intensa renúncia que funda a cultura - é apenas um lugar passageiro, apenas um teste, uma passagem para o aprendizado. $\mathrm{O}$ valor das ideias religiosas reside, também, na força daquilo que elas prometem.

Tudo que sucede nesse mundo é a realização dos propósitos de uma inteligência superior, que, embora por vias e desvios nada fáceis de acompanhar, termina guiando tudo para o bem, ou seja, para o que nos contenta. Cada um de nós é velado por uma Providencia bondosa, só aparentemente severa, que não permite que nos tornemos joguetes de força naturais poderoso e implacáveis. A própria morte não é aniquilação, retorno à inorgânica ausência de vida, mas sim o começo de uma nova espécie de existência que se acha no caminho para um desenvolvimento superior. (FREUD, 2014, p.251)

Suporta-se tudo quando se há outra casa quente e confortável à nossa espera. A morte, aquilo que a guerra nos escancara gerando dúvidas a respeito de nossa civilização (FREUD, 2010a), é vencida. A finitude é extirpada do horizonte. Tal como cada desamparo pudera ser resolvido pela figuração infantil, assim também a vida com suas dificuldades poderá repousar nos braços de Deus. O que Freud possibilita vincular com essa chave desamparo/religião é que dentre todas as armas da cultura a religião é a mais poderosa pois oferece um sentido para a vida, uma razão para a existência. Um repouso ontológico. Por isso podemos justificar melhor, dentro do panorama tratado, por que falar sobre a visão religiosa em Freud. Porque ela só ganha sua legitimidade quando compreendermos seu fundo possibilitador - como um bom kantiano inverso, o a priori para legitimar a religião em Freud é o desemparo insuportável -, isto é, a finitude. As análises da produção delirante da religião - desconexa com a obviedade da finitude mundana - mostram o homem por detrás dos altares: desespero, angústia, medo, corações da negatividade.

Logo, é ao desamparo universal que a religião vem responder, e não a um sentimento de integração - como se suponham defensores do "sentimento oceânico" de pertencimento ao todo (FREUD, 2010c, p.15). De fato, entre todas as armas da cultura a religião é a mais poderosa, e mais uma vez, vemos o motivo, ela é a única que pode responder pela finalidade da vida, a única que oferece todas as respostas. Melhoramos: a única que mascara sofisticadamente a negatividade da existência humana. A mais poderosa, porque os homens são desesperados e finitos.

A questão da finalidade da vida humana já foi posta inúmeras vezes. Jamais encontrou resposta satisfatória, e talvez não a tenha sequer. Muitos dos que a puseram acrescentaram o seguinte: se a vida não tiver finalidade, perderá qualquer valor. Mas esta ameaça nada altera. Parece isto sim que temos o direito de rejeitar a questão. O seu pressuposto parece ser aquela verba soberba de que já conhecemos tantos exemplos. Ninguém fala sobre a finalidade da vida dos animais, e menos que ela consista em servir aos homens, talvez... novamente apenas a religião sabe responder a finalidade da vida. Dificilmente erramos, ao concluir que a ideia de uma finalidade na vida existe em função do sistema religioso. (FREUD, 2010, p.29)

Para a cruel constatação de que em "todo arranjo do universo... podemos dizer que a intenção de que o homem seja feliz não se acha no plano da 'criação' (FREUD, 2010, p.30) há uma resposta pronta que já nos é dada de nascimento: esta vida é transitória e logo alcançará seu verdadeiro lar. "As pessoas acreditam não poder suportar a vida, se não derem a tais concepções o valor que é reivindicado para elas" (FREUD, 2014, p.253). Freud pontua que a cultura oferece para os homens as respostas prontas para aguentar as mazelas da natureza, do destino, da morte e da própria cultura: de fato, a vasta maioria de nós nasce inserida na herança religiosa, em sua atribuição de sentido para vida, e deste modo, a finalidade última de todo sofrer está respondida já no nascimento. Com Freud, vemos que ao homem sartreano que 
tende desesperadamente para o ser, para tapar o buraco da finitude, são concedidas respostas para dissipar a negatividade desde antes do sujeito ser capaz de dizer $\mathrm{Eu}^{23}$

Se Sartre nos impedia de atingir o Em-si, jamais seremos o ser, a plenitude, repouso, Freud nos mostra de que modo, no caso de atingi-lo - e muitos estão convencidos do encontro com Deus -, trata-se de uma ilusão. Que é uma ilusão? Não é erro, pontua Freud. Erro é algo muito mais simples - embora a tradição filosófica tenha que dar grandes saltos para inocentar Deus do erro dos homens. Erro é a desatenção de uma operação matemática, por exemplo. Ilusão é outra coisa. Ilusão é um erro motivado por um desejo (FREUD, 2014). Isto é: precisa-se, por força ontológica, diríamos, crer no erro. Desejo de contornar a finitude: deus, desejo de que tudo isso que nos cerca seja um "processo de desenvolvimento da consciência", e logo, totalização e identidade: repouso da plenitude. Desejo que a morte seja uma aparência: onde eu estiver ela não está, onde ela se colocar eu não estarei, pensa Epicuro. Mas, de fato, ela está aqui inserida exatamente aqui. A radicalidade da finitude em Freud é impedir o acesso ao absoluto pela presença maciça de um aparelho mental, de saída, finito e que exatamente por isso reconstrói o mundo à mercê de seus desejos. Eis a psicopatologia religiosa em Freud, a perda da realidade na psicose pode servir de modelo à transformação da mesma realidade pela religião. Delírio de massas, sistema autoritário de crenças, legitimação do sofrimento. A radicalidade da negatividade encontra inclusive, na psicanálise, sua correspondente com a medicina à época de Freud. Foucault (1966) pontua que a modernidade se ergue na analítica da finitude, tradição cuja ontologia cartesiana da subjetividade plena era gradativamente demolida. A psicanálise tem papel crucial como descentralizadora desta dimensão do idêntico a si mesmo. Desembocado o Eu, eis o sombrio Id. A inserção da dimensão inconsciente nas formulações freudianas altera profundamente o rumo da positividade do cogito e da existência humana em geral.

Se no início do percurso teórico Freud apostou numa concepção vitalista do organismo - mesmo anímico (BIRMAN, 2010) - através da pulsionalidade regulada pelo princípio de prazer como fundante do aparelho psíquico e a sexualidade como registro da vida, nos anos 1920, a coisa muda de quadro. Uma guinada a baixo, diríamos, negatividade. A pulsão de morte fora inserida no âmago do sujeito, sua própria destruição. Discurso mortalista (BIRMAN, 2010, p.41), a letra freudiana põe ênfase no "além do princípio do prazer", tornando a repetição e a morte primados sobre a vida. Mais uma vez, desamparo, limitação. Mas nos entendamos. Em si mesma, a atribuição de mau, bom, belo, feio não existe na pulsão. Ela busca expressar, exige trabalho, a negatividade está no frágil Eu lidando com as agruras de si próprio. Este si que, contudo, é menos seu do que parece. A radicalidade da finitude na psicanálise freudiana poderia estender-se ainda muito longe. Mas paramos aqui, diante o desamparo, os rastros de um desejo que exige uma crença delirante, diante da impossibilidade de uma formação da consciência, pois a mesma consciência, para Freud, é mediadora de conflitos e não uma Ideia. ${ }^{24}$

\footnotetext{
${ }^{23} \mathrm{E}$ o fundamental é que através da incorporação da cultura pela subjetividade nascente, o edifício religioso em toda sua construção delirante é facilmente acolhido por uma criatura de profundas negatividades existenciais. Talvez a grande contribuição na explicitação da religião por Freud se dê na exata medida em que se elucida o funcionamento mental em sua complexidade subjacente à necessidade religiosa. Estruturalmente analisada, a fé é um componente tão legítimo de análise como um sonho ou um ato falho.

${ }^{24}$ “Na segunda metade do século XX, a filosofia alemã promoveu um retorno teórico a Kant e uma crítica sistemática a Hegel, movimento conhecido como neo-kantismo. A ciência alemã se engaja nesta elegia e nesta oposição, enfatizando com isso a relevância teórica da ruptura. Nesta conjectura, o que está em causa é a crítica de uma concepção totalizante do saber, representada pela filosofia hegeliana. Assim, é face ao discurso filosófico com pretensão de ser uma visão de mundo, uma weltanchsauung, que se retoma a filosofia kantiana, de maneira a conferir a devida especificidade aos saberes particulares. Foi nessa tradição que se inseriu Sigmund Freud... estava reafirmando não sua oposição ao discurso filosófico no sentido genérico, mas a uma filosofia com pretensão totalizante, como historicamente foi representada a filosofia hegeliana" (BIRMAN, 1991, p.164).
} 
Fica claro que Hegel é um filósofo da negatividade, mas como bem pontuaria Adorno, sua negatividade é positiva, e isto o leva a uma reconciliação final de consequências amplas e graves na dimensão social, por exemplo (REPA, 2011). Mergulho sem volta no seio da separação, a cisão sartreana não comporta um futuro onde a identidade de sujeito e objeto será atingida. Mergulho sem volta igualmente, a dimensão humana na visão freudiana é fadada à sua própria finitude. A positividade é do ser, não há alteridade nele, nunca se põe como relação ao outro, cabe à consciência, vazia e apanhada na contingência radical, nostálgica de identidade, de reconciliação, permanecer na negatividade, diria Sartre. Projeto de ser que nunca se completa, desejando não ser nada, sua liberdade é também seu desespero. Projeto de saciar a pulsionalidade incessante, desejando os deuses e a solução para a finitude, cada oração para os céus, em Freud, devolve-nos para nossa própria carência e frustração: os céus sempre nos devolverão, como um espelho, nossa imagem invertida. Quem não desconfiaria, após Freud, que a onipotência elegante tem mesmo pijamas de angústia?

Correspondência: Fábio Moreira Vargas. Universidade de São Paulo - USP. Departamento de Filosofia, Letras e Ciências Humanas - FFLCH. Av. Prof. Luciano Gualberto, 315, sala 1007. Cidade Universitária. São Paulo - SP - Brasil. CEP: 05508-010. E-mail: fabio.vargas@usp.br

Conflito de interesses: Nenhum

Todos os autores leram e aprovam a versão final submetida à revista Em curso. 


\section{Bibliografia}

BIRMAN, J. Discurso freudiano e medicina. In: BIRMAN, J; FORTES, I; PERELSO, S. (Org.) Um novo lance de dados. Psicanálise e Medicina na contemporaneidade. Rio de Janeiro: Cia de Freud, 2010. pp.13-46.

. Fantasma, Verdade e Realidade. In: BIRMAN, J; DAMIÂO, M, M. (Org). Psicanálise: Ofício impossível? Rio de Janeiro: Editora Campus, 1991, pp.157-178.

BORNHEIM, G. Sartre, Metafísica e Existencialismo. São Paulo: Perspectiva, 1971.

FIGUEIREDO, L. C. Matrizes do pensamento psicológico. Rio de Janeiro: Vozes, 2014.

FOUCAULT, M. Le Mots et les choses. Paris: Gallimard, 1966.

. O que é um autor? Tradução de Inês Autran Dourado Barbosa. In: MOTA, M. B. (Org.) Estética: literatura e pintura, música e cinema (Ditos e Escritos Vol. III). Rio de Janeiro: Forense Universitária, 2001.

FREUD, S. Projeto para uma psicologia científica. Tradução de Christiano Monteiro Oiticica Rio de Janeiro: Editora Imago, Vol. I, 1976.

. Totem e Tabu. Tradução de Renato Zwick. São Paulo: L\&PM, 2013.

. Considerações atuais sobre a Guerra e a morte. Tradução de Paulo César de Souza. São Paulo: Cia das Letras, 2010a.

. O Futuro de uma ilusão. Tradução de Paulo César de Souza. São Paulo: Cia das Letras, 2014.

Novas conferências introdutórias à psicanálise. Tradução de Paulo César de Souza. São Paulo: Cia das Letras, 2010b.

. O Mal-estar na civilização. Tradução de Paulo César de Souza. São Paulo: Cia das Letras, 2010c.

O Eu e o Id. Tradução de Paulo César de Souza. São Paulo: Cia das Letras, 2011.

. Introdução ao Narcisismo. Tradução de Paulo César de Souza. São Paulo: Cia das Letras, 2010d.

FOUGEYROLLAS, Pierre. Contradiction et Totalité. Paris, Les Editions de Minuit, 1964.

HEGEL, G. W. F. Fenomenologia do Espírito. Tradução de Paulo Meneses. Rio de Janeiro: Vozes, 2016.

HYPPOLITE, Jean. Gênese e Estrutura da Fenomenologia do Espírito de Hegel. Tradução de Andrei José Vaczi, Denílson Soares Cordeiro, Gilberto Tedéia, Luis Sérgio Repa, Rodnei Antônio do Nascimento. São Paulo: Discurso Editorial, 2003.

KANT, I. Crítica da Razão Pura. Tradução de Fernando Costa Mattos. Rio de Janeiro: Vozes, 2012.

REPA, Luis Sérgio. Totalidade e Negatividade: a crítica de Adorno à dialética hegeliana. Salvador, Caderno CRH, v. 24, n. 62, pp.273-284, 2011.

SANTOS, José Henrique. Trabalho e Riqueza na Fenomenologia do Espírito de Hegel. São Paulo: Loyola, 1993.

SARTRE, Jean-Paul. O Existencialismo é um Humanismo. Tradução de Paulo Perdigão. Rio de Janeiro: Vozes, 2014.

. O Ser e o Nada. Tradução de Paulo Perdigão. Rio de Janeiro: Vozes, 2016.

SILVA, Franklin Leopoldo. Para a compreensão da história em Sartre. Paraná: Universidade do Oeste do Paraná, Tempo da Ciência, Vol. 11. n. 22, 2004.

Recebido em: 30/Mar/2017 - Aceito em: 17/Nov/2017. 